\title{
Politics, diversity and the distribution of federal disaster assistance
}

\author{
Richard M. Vogel $^{1^{*}}$ \\ ${ }^{1}$ School of Business, Farmingdale State College, United States
}

\begin{abstract}
Using a database of natural hazard events and costs that have struck the U.S. since 1964, this paper evaluates the distribution of federal disaster assistance in light of state electoral politics, population diversity, and other demographic factors. The results of the analysis indicate that electoral politics does appear to affect the distribution of federal disaster aid. More to the point, it tends to show that Republican leaning states receive less federal aid than Democratic leaning states.
\end{abstract}

Keywords: disaster assistance, federal policy, presidential disaster declaration JEL Classification Codes: H84, R50

\section{Introduction}

Damages from natural and manmade hazards and disasters in the United States average $\$ 12$ billion annually. While individual disaster occurrences and their associated impacts tend to be relatively localized, they may overwhelm state, local, and private resources within the region to both respond to the event and to provide funding and materials necessary for post-disaster relief and recovery activities. Since 1953, with the issuance of the first Presidential Disaster Declaration, a statutory mechanism has evolved to channel federal emergency resources to the state and local level. Of concern though is the extent to which electoral and party politics affects this process.

Analysts such as Sylves (2005) and Moss, Schelhammer and Berman (2009) point out that there is a well defined process for Presidential disaster and emergency declarations to take place. The key legislation for this process is the Stafford Act of 1988 (amended in 2000). In brief, the governor of the affected state must make a request to the President before a federal disaster declaration can be issued. Subsequent legislation such as the Homeland Security Act of 2002 and Post-Katrina Emergency Reform Act of 2006 have established procedures that make it possible for the President

*Corresponding author. E-mail: richard.vogel@farmingdale.edu.

Citation: Vogel, R.M. (2012) Politics, diversity and the distribution of federal disaster assistance, Economics and Business Letters, 1(2), 37-42. 
to bypass the initial step of a governor's request, but only under proscribed circumstances.

Using a database of natural hazard events and costs that have struck the U.S. since 1964, this paper evaluates the distribution of federal disaster assistance in light of state electoral politics, population diversity, and other demographic factors. The focus is upon state electoral politics and the level of federal aid to states. Over the last three decades, one of the major areas of contention between the two major political parties in the country is the size of government and the level of services provided by the federal government to its citizens. Does a state's predominant party affiliation affect the level of disaster aid that it receives? This is the primary question evaluated by this analysis. In the next section of this paper, the federal government's role in disaster relief is outlined and the literature on the political process on disaster relief is discussed. Section 3 presents the model and data used for the analysis. The results of the analysis are presented in Section 4 and the conclusions of this study are presented in Section 5.

\section{Discussion}

The Stafford Act established two classes of disasters, 'major emergencies' and 'emergencies'. A 'major emergency' is a situation as determined by the President in which the damage is of sufficient severity that major disaster assistance is warranted. An 'emergency' refers to a situation in which federal assistance could not exceed $\$ 5$ million unless the President determines otherwise. The statutory rate for federal disaster relief is 75 percent federal, with 25 percent matching from the state or local government entity. This federal reimbursement rate can be adjusted up by the President as he or she would deem appropriate. A Presidential disaster decree allows a variety of different types of federal aid that could potentially flow into the state including direct assistance to households, small business loans, and funding to state and local government to rebuild government facilities and infrastructure.

The process for requesting and issuing a Presidential disaster decree combines both a factual and a political component to it. Over the last fifteen years, studies such as Wamsley and Schroeder (1996), Garrett and Sobel (2002), and Gasper and Reeves (2010) have all concluded that electoral politics have impacted the disaster declaration process tremendously. Sylves (2005) points out that over time the rate at which governors' requests for a disaster declaration would be turned down has fallen from 33 percent to 25 percent. Since 1953, the number of requests from states for disaster declarations has increased, and since 1988 has expanded dramatically. Wamsley and Schroeder (1996) suggest several possible reasons for this increase including the impact of new media outlets such as CNN on the news cycle and a greater focus upon the political consequences from not responding.

Garrett and Sobel (2002) develop an econometric model of the approval process which accounts for both presidential and gubernatorial politics. They find politically important states have a higher number of disaster declarations. Gasper and Reeves (2010), using monthly data on disaster declarations and requests, find that governors act opportunistically in making disaster declaration requests suggestive of trying to leverage the electoral importance of their states.

Bagstad, Stapleton and D'Agostino (2007) and Dirmeyer (2009) evaluate federal disaster assistance in terms of potential unintended consequences. In particular, Bagstad et al (2007) suggest that government programs such as the provisions of the Stafford Act, the National Flood Insurance Program, and activities of the Army Corps of Engineers have all led to increasing disaster vulnerability. These programs have 
essentially created a situation that subsidizes individuals to live in and move into hazardous zones, particularly coastal areas and flood plains. They also raise the specter of political manipulation that can arise from disaster relief programs as Presidents adjust the rate from the statutory $75 / 25$ formula to 90 percent or higher. Dirmeyer (2009) finds that federal aid reduces the competitiveness between local communities that would otherwise arise through a Tiebout type process. She also finds that federal aid programs may exacerbate coordination failures that slow population and regional recovery.

Smith and Watts (2010) suggest that any type of federal relief from disaster is likely to cause a form of moral hazard to arise. While the focus of their discussion is upon agricultural disaster relief programs and in particular the Supplemental Disaster Assistance Program (SURE) enacted in 2008, the argument can be extended to any type of federal assistance. The SURE program provides automatic disaster relief to farmers that experience crop losses in excess of 50 percent of their average output. Simulations conducted by Smith and Watts demonstrate that depending on the federal disaster insurance contracted price for any particular crop and the market price, the SURE system may create a disincentive to farmers to take all necessary steps to protect their crops. This argument of course can be extended to all types of federal disaster assistance, and suggests that individuals may not necessarily take all of the steps to mitigate potential disaster situations that they otherwise should - especially if they know that federal assistance will be readily forthcoming. Michel-Kerjan and VolkmanWise (2011) further extend this line of reasoning suggesting that the federal disaster relief creates a cycle whereby elected officials have no alternative but to keep on offering ever increasing levels of disaster relief.

\section{Evaluation of the issue}

Federal disaster relief is evaluated using the framework of a modified production function. Considering the level of federal disaster relief (FDR) to be the output in this instance and the inputs for state aid to consist of Presidential Disaster Declarations (PDD), demographic characteristics such as population (Pop) and per capita income (PCY), and the political makeup of the state (Pol), the level of disaster relief flowing to each state is modeled as:

$$
F D R_{t}=\alpha+\beta_{1} P D D_{t}+\beta_{2} \text { Pop }_{t}+\beta_{3} \text { Pol }_{t}+\beta_{4} P C Y_{t}+\varepsilon_{t}
$$

The total amount of disaster relief flowing to each state is estimated using the number of PDDs issued to each state annually, state population, and per capita state income. A second version of the equation estimated is:

$$
F D R p c_{t}=\alpha+\beta_{1} P D D_{t}+\beta_{2} P \operatorname{Den}_{t}+\beta_{3} \text { Pol }_{t}+\beta_{4} P C Y_{t}+\varepsilon_{t}
$$

where FDRpc represents per capita disaster relief and PDen is the population density in each state. Both versions of the equation are evaluated in log form and include a time trend variable.

Data (Table 1) on both FDR and PDDs was collected from the Public Entity Risk Institute for the periods from 1953 through 2009. Their data are compiled from Federal Emergency Management Agency (FEMA) sources but also include material not readily available from FEMA. FDR is adjusted for 2009 constant dollars. The data from 2009 only includes disaster declarations and relief through the third quarter. Data on state population, 1958-2009, and per capita income, 1958-2009, were collected from the Bureau of Economic Analysis. Per capita income utilized in the analysis is in the form of individual percentage of national income by state. PDen is calculated as BEA state 
population divided by state land area collected from the Statistical Abstract of the United States 2012. Data on state results from presidential elections, 1964-2008 was collected from the Statistical Abstract of the United States. Summary data for all of the variables are presented in Table 2.

The data is analyzed as a full panel from 1964 to 2009. Four hypothesis are evaluated in the analysis: 1) Political affiliation of the state (Republican/Democrat) will affect the distribution of federal aid; 2) Population growth will positively impact state aid; 3) Population density, or what can also be termed urban/rural variation will impact the distribution of state aid; and 4) higher levels of state income will positively impact federal aid levels.

Table 1. Variable names and definitions

\begin{tabular}{|c|c|c|c|}
\hline Variable & Definition & Years & Source \\
\hline FDR & Federal Disaster Relief & $\begin{array}{l}1953- \\
2009\end{array}$ & PERI \\
\hline FDRpc & Per Capita Disaster Relief & $\begin{array}{l}1958- \\
2009\end{array}$ & $\begin{array}{l}\text { PERI, Statistical Abstract of the } \\
\text { U.S. } 2012\end{array}$ \\
\hline PDD & Presidential Disaster Declaration & $\begin{array}{l}1953- \\
2009\end{array}$ & PERI \\
\hline POL & $\begin{array}{l}\text { State Political Outcome, Presidential } \\
\text { Elections: Equal to } 1 \text { if Republican, } 0 \\
\text { otherwise }\end{array}$ & $\begin{array}{l}1964- \\
2009\end{array}$ & Statistical Abstact of the U.S. 2012 \\
\hline Pop & State Population & $\begin{array}{l}1958- \\
2009\end{array}$ & Bureau of Economic Analysis \\
\hline PDen & $\begin{array}{l}\text { State Population Density: Pop/(State Land } \\
\text { area in Square Miles) }\end{array}$ & $\begin{array}{l}1958- \\
2009\end{array}$ & $\begin{array}{l}\text { Bureau of Economic Analysis; } \\
\text { Statistical Abstract of the U.S. } \\
2012\end{array}$ \\
\hline PCY & $\begin{array}{l}\text { State Percentage of National Per Capita } \\
\text { Income }\end{array}$ & $\begin{array}{l}1958- \\
2009\end{array}$ & Bureau of Economic Analysis \\
\hline
\end{tabular}

Table 2. Summary data used for analysis

\begin{tabular}{lrrrrrrr}
\hline \hline & FDR & FDRpc & PDD & POL & Pop & PDen & PCY \\
\hline \hline Mean & 52885.51 & 12.93318 & 0.680733 & 0.601876 & 4664075 & 369.8764 & 96.43611 \\
Median & 0 & 0 & 0 & 1 & 3143500 & 81.67128 & 94.69 \\
Maximum & 30121666 & 6581.629 & 7 & 1 & 36961229 & 13081.97 & 179.29 \\
Minimum & 0 & 0 & 0 & 0 & 224000 & 0.460866 & 57.69 \\
Std. Dev. & 707716 & 162.145 & 0.920709 & 0.489616 & 5193740 & 1476.743 & 15.48889 \\
Observations & 2652 & 2346 & 2346 & 2346 & 2652 & 2346 & 2346 \\
Cross sections & 51 & 51 & 51 & 51 & 51 & 51 & 51 \\
\hline \hline
\end{tabular}

\section{Results of the analysis}

The analysis was conducted using pooled OLS with cross section and period weighting. There were some stationarity issues with two of the variables Pop and PCY, though not across all states. A trend variable is included in the analysis to correct for stationarity problems. The results of the analysis are presented in Table 3. 
Table 3. Regression Results, Pooled OLS - Dependent Variable FDR and FDRpc: 1964-2009

\begin{tabular}{|c|c|c|c|c|c|}
\hline Variable & Coefficient & Elasticity & Variable & Coefficient & Elasticity \\
\hline$\overline{\mathrm{C}}$ & $\begin{array}{l}7.28657 * * * \\
(1.306)\end{array}$ & & $\overline{\mathrm{C}}$ & $\begin{array}{l}-1.39292 \\
(1.4263)\end{array}$ & \\
\hline PDD & $\begin{array}{l}0.60434 * * * \\
(0.046)\end{array}$ & 0.008 & PDD & $\begin{array}{l}0.49937 * * * \\
(0.043)\end{array}$ & 0.339 \\
\hline LOG(Pop) & $\begin{array}{l}0.36392 * * * \\
(0.039)\end{array}$ & 0.363 & LOG(PDen) & $\begin{array}{l}-0.41468 * * * \\
(0.033)\end{array}$ & -0.414 \\
\hline POL & $\begin{array}{l}-0.10717 \\
(0.083)\end{array}$ & -0.064 & POL & $\begin{array}{l}-0.27794 * * * \\
(0.088)\end{array}$ & -0.167 \\
\hline LOG(PCY) & $\begin{array}{l}0.47646^{*} \\
(0.279)\end{array}$ & 0.476 & LOG(PCY) & $\begin{array}{l}0.70661 * * \\
(0.315)\end{array}$ & 0.706 \\
\hline TREND & $\begin{array}{l}0.02368 * * * \\
(0.003)\end{array}$ & & TREND & $\begin{array}{l}0.02635^{* * * *} \\
(0.003)\end{array}$ & \\
\hline $\operatorname{Adj} R^{2}$ & 0.9125 & & $\operatorname{Adj} R^{2}$ & 0.2830 & \\
\hline
\end{tabular}

Level of significance: $* 0.10, * * 0.05, * * * 0.01$

Overall, estimated coefficients on population, presidential disaster declarations and per capita income are consistent with a priori expectations. They all positively impact the level of both federal disaster relief and per capita federal disaster relief. The coefficient on population density was both negative and significant. The analysis suggests that greater population density reduces per capita federal disaster relief. In both equations, the time trend variable was estimated to be both positive and significant. This result is consistent with other studies in the literature and indicative of a continually rising level of federal disaster assistance over the period.

The coefficient on state electoral outcomes is of the greatest interest in the analysis. In the case of Equation 1, the coefficient is not statistically significant, but it is estimated to be negative. For equation 2, it is negative and statistically significant, indicative that Republican States receive lower levels of federal disaster assistance than Democratic states. This result is consistent with studies that suggest that electoral politics plays a role in the allocation of disaster assistance.

\section{Conclusions}

The analysis indicates that electoral politics does appear to affect the distribution of federal disaster aid. More to the point, it tends to show that Republican leaning states receive less federal aid than Democratic leaning states, and is consistent with the oftstated viewpoint of Republican politicians of their interest in reduced government. Whether this outcome is the result of specific electoral politics, presidential actions, or state officials is not readily determined from the analysis - but likely arises from all three sources.

This study is part of an ongoing analysis of hazards in the United States and their overall impact on growth and development. The current political discourse on the interrelationship between the role of government, market activities, and the choices and decisions of individual agents appears to be diverging into two distinct and vocal camps - one favoring limited government action, and a centrist position suggesting that government has some important functions to carry out beyond national defense. As with all policy issues, the public response to natural and manmade hazards is as much a political question, as it is an economic or social concern. 


\section{References}

Bagstad, K.J., K. Stapleton and D'Agostinoa, J.R. (2007) Taxes, subsidies, and insurance as drivers of United States coastal development, Ecological Economics, 63, 285-298.

Bureau of Economic Analysis, Regional Economic Accounts. $<$ http://www.bea.gov/regional/index.htm>.

Dirmeyer, J. (2009) The political economy of local governance and service provision, Unpublished doctoral dissertation, George Mason University.

Garrett, T.A. and Sobel, R.S. (2002) The political economy of FEMA disaster payments, Working Paper 2002-012B, Federal Reserve Bank of St. Louis, St. Louis, MO.

Gasper, J.T. and Reeves, A. (2010) Governors as opportunists: evidence from disaster declaration requests, SSRN paper id SSRN-id-1642672.

Michel-Kerjan, E. and Volkman-Wise, J. (2011) The risk of ever-growing disaster relief expectations, Working Paper 2011-09, Risk Management and Decision Processes Center, The Wharton School, University of Pennsylvania.

Moss, M., C. Schellhamer and Berman, D. (2009) The Stafford Act and priorities for reform, Journal of Homeland Security and Emergency Management, 6(1), 1-23.

Public Entity Risk Institute, Summary Data. (Data Presidential Disaster Declarations and Federal aid to states associated with these declarations) <http://www.peripresdecusa.org/mainframe.htm>.

Smith, V.H. and Watts, M. (20109 The new standing disaster program: a sure invitation to moral hazard behavior, Applied Economic Perspectives and Policy, 32(1), $154-169$.

Sylves, R. (2005) Presidents, disasters and policy, Public Entity Risk Institute. $<$ http://www.peripresdecusa.org/mainframe.htm>.

United States Census Bureau (2012) The 2012 Statistical Abstract (various data). $<$ http://www.census.gov/compendia/statab/>.

Wamsley, G.L. and Schroeder, A.D. (1996) Escalating in a quagmire: the changing dynamics of emergency management policy subsystem, Public Administration Review, 56(3), 235-244. 